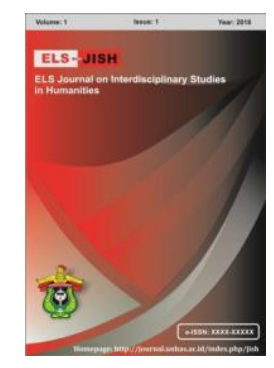

ELS-JISH

ELS Journal on Interdisciplinary Studies on Humanities

Volume 3 Issue 2, 2020

ISSN (print) : 2621-0843

ISSN (online) : 2621-0835

Homepage : http://journal.unhas.ac.id/index.php/jish

\title{
The Effect of Motivation and Anxiety on Students' Speaking Performance: A Study at Dayanu Ikhsanuddin University
}

\author{
Sitti Nur Aisyah Ritonga ${ }^{1}$, Nasmilah$^{2}$, Fathu Rahman ${ }^{3}$ \\ 1 aisyahritonga123@gmail.com
}

\begin{abstract}
This study aims to know the effect of motivation and anxiety on students' speaking performance: a study at Dayanu Ikhsanuddin University. The study was designed in the form of quantitative and qualitative descriptive studies (mixed methods). Subjects in this study were the 5th semester students of the teaching and education study program in Dayanu Ikhsanuddin University who took the speaking class as part of their courses. The data were collected by using the methods of observation, interviews, and questionairre. Data were analyzed through triangulation data. The results showed that language anxiety felt by students during their speaking presentation in English might result in their inability to deliver ideas clearly and this would have a negative impact on their performance. In contrast, langauge motivation during speaking presentation would help students to feel less anxious and be more concentrated on the task and would result in a better speaking performance.
\end{abstract}

Keywords: Motivation, Anxiety, Student's Speaking Performance.

How to cite: Ritonga, S. N. A., Nasmilah.,\& Rahman, F. (2020). The Effect of Motivation and Anxiety on Students' Speaking Performance: A Study at Dayanu Ikhsanuddin University. ELS Journal on Interdisciplinary Studies in Humanities, 3(2), 198-213. DOI: 10.34050/els-

jish.v3i2.10263

\section{Introduction}

English is one of the major languages in the world and has been chosen and accepted as an international language. The role of English language in Indonesia is becoming more significant which can be seen clearly in some aspects of society life.

In educational sector, English language is taught compulsorily at public schools starting from secondary school to the freshman year of the university or college. According to Rahman (2018: 1-2) English is widely taught as a foreign language, in particular in Indonesia, The education system in Indonesia is very aware of the importance of English. In addition to the language of science and technology, it is also widely used as a means of international communication. So the English teaching and learning proccess is very meaningful for the development of education in Indonesia. There are some factors that influence the teaching of English as a foreign language in Indonesia. They are: mother

1,2,3 Universitas Hasanuddin, Indonesia. 
tongue, motivation, social, culture, anxiety and some other determining factors Krashen (1985).

Anxiety owned by students is one of the factors that play a profound role in learning English. The level of language anxiety possessed by someone really determines the learning process. Anxiety problem in the learning process has become a serious concern. At school, many factors trigger anxiety on students. From curriculum factor, the high target of curriculum, inefficient learning atmosphere, lots of assignments and a rigorous and unfair assessment system can be factors of anxiety. Likewise, from the teacher factor, the attitudes and treatment of unfriendly, killer and less competent teachers are also another source of students' anxiety. In addition, the application of strict school discipline that prioritizes punishment, the school atmosphere that is less comfortable as well as the limited facilities and infrastructure are the formation of students' anxiety coming from management factor.

Language anxiety is anxiety that arises when someone learns English. Anxiety is a major factor that can hamper the learning process. Anxiety itself is a subjective feeling of tension (tension), the state of apprehension, nervousness and worry associated with the stimulation of the autonomic nervous system caused by vague fear which is not directly related to the object. According to Wolman and Stricker (1994), Foreign Language Anxiety (anxiety of learning a foreign language) is a concern or negative emotional reaction that comes when learning or speaking English. Understanding of Foreign Language Anxiety is "distinct complex of self-perceptions, beliefs, feelings, and behaviors associated with classroom language learning arising from the uniqueness of the language learning process". Foreign Language Anxiety consists of three dimensions, namely communication apprehension, test anxiety and fear of negative evaluation. Gebhard (1996) stated that English teaching and learning process is directed to make students understand and analyze English in order to to pass the exam. In facts, education in Indonesia provides little opportunity for students to implement communicatively outside the school of what they have learn. As a result, English teaching and learning process only emphasize on "learning about English" rather than "learning how to use English".

The other factor influencing the speaking performance is motivation. It can generate power, stimulate a person to do something and achieve a certain satisfaction or purpose. It takes a boost within the students themselves in order to create an atmosphere of effective teaching and learning process. According to Ellis (2008) motivation if it were viewed from the side of foreign language acquisition is an affective attitude or condition that influences the level of students' efforts in learning a foreign language. Meanwhile, Brown (2000) stated that motivation is a choice taken by someone to gain experience or purpose and efforts in order to reach the objective. Motivation is divided into several groups. Ellis (2008) classified motivation into four parts namely, instrumental, integrative, resultative and intrinsic, then Brown (2007: 188) adds extrinsic as another type of motivation.

At English Department of Dayanu Ikhsanuddiin University, when analyzing the syllabus, speaking is taught for three semesters starting from semester III (Speaking1), semester IV (speaking 2) up to semester VI (speaking III). The 
way of teaching in Dayanu Ikhsanuddin University is less communicative. The teaching approachment is still traditional in which accuracy is given more emphasis than fluency. Furthermore, when I did preliminary studies on speaking 1 and 2, students who took the speaking class had a variety of traits often called individual differences. Individual differences are a term that underpins the things that I tried to explore in this study. There were some who had high anxiety when attending speaking class while the rest was not, and the motivations that they have vary. Thus, I am interested to analyze deeply of to what extent anxiety and motivation affect student learning outcomes. Based on the investigation and reasons above, the researcher decided to chose the topic entitled "The Effect of Motivation and Anxiety on Students' Speaking Performance: A study at Dayanu Ikhsanuddin University".

\subsection{Objectives of the Study}

The objectives of this study were formulated as follows: 1). To find out the effect of anxiety and motivation in students' speaking performance of EFL students in Dayanu Ikhsanuddin University, 2) To reveal how students control their anxiety during speaking.

\section{Method}

\subsection{Research Location}

Research Location is a place to conduct research in order to obtain research data. The research was carried out in the Dayanu IKhsanuddin University, located in Jalan Dayanu, Baubau city.

\subsection{Respondents}

The population of this research was the 5th semester students of the Faculty of Teacher Training and Education (FKIP) in Dayanu Ikhsanuddin University. Based on the preliminary study, the class in the faculty of teacher training and education was divided into five classes in which the numbers of every class were 39-42 students. The total numbers were 220 students. By applying random sampling technique, the researcher took 3 classes to be observed which are A, C, and E classes.

\subsection{Respondents}

The subjects of this study were the teachers and the students of an English institution named TAF English where the teachers were usually referred to as coach (es) so the term coach and teacher may be used interchangeably but they refer to the same object. During the study, there were five cases observed meaning that there were five observed classes with one coach and one student for each class. The choosing of the subjects concerned to any learning schedules of Intensive Speaking Program that were available to be observed in the institution meaning that the students confirmed to come and to have the class. Besides, the private setting of the program was also one of the considerations. Private setting referred to the condition of one-on-one teaching and learning class where each individual student was given lesson by a coach so there were only two of them in the classroom. 


\subsection{Procedure}

The researcher collected the data by using observation, interview, and questionnaire. Observation would be used during the teaching and learning process to make deep analysis of the activity. So, the researcher would directly witness the observed object. The second is interview sessions would help to obtain the real object about the constraints faced by the lecturers and the students in English speaking. Interviews would be conducted in different times. At first, the researcher interviewed the lecturer while the students would be interviewed on the following day. Such techniques are applied to match the information obtained from the lecturer with the real context during the teaching and learning process as well as to find out the response from students about the lesson being delivered. Finally, questionnaire is a useful tool to collect information of psychological factors (motivation and anxiety) and other components related to this study.

\subsection{Data Analysis}

The data obtained from the questionnaire were analyzed to depict the frequency of occurrence of each possible response. The data would be focused to describe the learning process at Dayanu Ikhsanuddin University. Researcher would use closed ended questions, open-ended questions, and semi closed questions in questionnaires. To analyze and interpret the data obtained from the questionnaire, the researcher used the statistic simple formula. The data will be presented using the following formula.

$$
P=\frac{F}{N} X 100 \%
$$

Note :

$$
\begin{aligned}
& P=\text { Percentage } \\
& F=\text { Frequency } \\
& N=\text { Number of sample } \\
& 100 \%=\text { Constants value }
\end{aligned}
$$

The data obtained from observation and interview were used as additional information to back up the questionnaire data. Then, those data would be interpreted qualitatively

\section{Findings}

\subsection{The Result of Classroom Observation}

The researcher carried out the observation to find out the effect of motivation and anxiety on students' speaking performance. The researcher was conducted the research from 2nd December 2019 till 3rd January 2020. There were five classes in this major and the speaking subject was run twice a week. However, the researcher only took 3 classes $A, C$, and $E$ as the sample of the research. The reason was those samples were taken randomly and the lecturer's recommendation to research the classes with nearly similar ability to avoid the gap and to keep objective study. 
There were several categories of motivation and anxiety being asessed during the observation process (See; Appendices, Table 1). A course of work can be accomplished well by the motivated students. Dörnyei (1998) argues the importance of motivation by stating that motivation provides learners the primary stimuli for initiating second language learning, and later motivation become the driving force for learners to be persistent in tedious learning process, so that learners may be able to complete longterm goals. On the other words, students have eagerness to learn and it contributes to their learning outcome. Teachers should be creative enough to provide teaching material and media in order to prompt students' motivation in learning for a better outcome. Aswar, et al (2019) stated that teachers should play their best roles to choose the most proper learning media for their students. In the context of this research, there are the results that can be captured during the observation

a. Attentive; 78/121 students could keep their eyes on during the speaking lesson. They could participate starting from the opening till the closing.

b. Intiative to ask; 29/ 121 students were found initiative to ask some questions during the lecturing.

c. Confident to express idea; 15/ 121 students confidently delivered their ideas with English.

d. Engage actively in learning process; 53/ 121 students engage actively and lively during the lecturing. To illustrate, the students were initiative to take some notes and interersted into the given activities.

e. Lively interaction; from eight meetings, the researcher noticed that the lively interaction only happened in the first, fourth, fifthe, and seventh meeting.

f. Responsive; 13/ 121 students dared to answer the lecturer's question well.

Anxiety would bring negative influence to students especially when speaking English. (Greenberg, 2017) states that "anxiety is feelings of discomfort that people experience before, during, and after speaking in public". The basis of the statement is when the students feel anxious, student discomfort and not confident to speak in front of the class and anxiety makes the language learners nervous and afraid, which may contribute to poor oral performance (Morris, 2017). Based on the observation conducted, here are some anxiety that could be noticed during the lecturing.

a. Afraid of making mistake; one of the most problematic aspect in learning English is feeling doubt to make errors. This aspect stimulated the children not to speak up during the time given. 90/121 students were noticed dealing with this aspect.

b. Unconfident to come forward expressing ideas; not every student are willing to come forward expressing their ideas in English. Most students struggled a lot to be expressive. 
c. Nervousness; 65/ 121 students felt tremble hands and did improper acts during the speaking time.

d. Panic; 70/ 121 students were afraid to be pointed by the lecturer and shy to speak up. Sometimes, they left the room to go to the toilet as the reason to avoid their turns to speak.

\subsection{The Result of Structured Interview}

This study was also supported with the interview. The researcher interviewed the students and the teacher structurally. For the interviews, it does not matter how many participants it has so long as the research theoretical saturation (see Corbin \& Strauss, 2008). Saturation can only be determined in retrospect, however, the researcher will need more interviews than the point of saturation. In other words, 10 interviewees are needed before the researcher determines hitting saturations at interview 8. Also, saturation changes depending on the research question. So if the researcher wants to get more than one study from mixed method data, then the number of interviewees needed might vary. As for $6-8$, it is possible to hit saturation there if having a very simple question but it seems a bit unlikely. For a straight up thematic analysis, it wouldn't have less than 20. Thus, the researcher took 30 interviewess for 3 classes (10/ each). The selection of the participants was based on the students' classroom participation and attitude toward English class.

Table 1. Students' attitude toward their English Class

\begin{tabular}{|c|c|c|}
\hline Item & Effect of Anxiety & Effect of Motivation \\
\hline \multirow{2}{*}{$\begin{array}{l}\text { Q 1: How do you } \\
\text { feel about your } \\
\text { experience of } \\
\text { learning English? }\end{array}$} & $\begin{array}{l}\text { Hard, I don't understand my } \\
\text { lecturer, I don't know, } \\
\text { unclear. }\end{array}$ & $\begin{array}{l}\text { Great, nice, good but sometimes } \\
\text { need effort to understand, I like } \\
\text { English speaking. }\end{array}$ \\
\hline & Number of Interviewees: 17 & Number of interviewees: 13 \\
\hline \multirow[t]{2}{*}{$\begin{array}{l}\text { Q 2: Please tell me } \\
\text { what disturbs you } \\
\text { the most about } \\
\text { learning and } \\
\text { speaking English } \\
\text { and why? }\end{array}$} & $\begin{array}{l}\text { Coming to the front of the } \\
\text { class and speak, being } \\
\text { pointed so sudden by the } \\
\text { lecturer, shy to speak } \\
\text { because I don't know } \\
\text { English, when required to } \\
\text { give presentation I don't } \\
\text { know how to speak English }\end{array}$ & $\begin{array}{l}\text { Nothing because I like English, } \\
\text { no big problem because English } \\
\text { is my favorite, the lecturer } \\
\text { understands me so no problem }\end{array}$ \\
\hline & Number of interviewees: 22 & Number of interviewees: 8 \\
\hline \multirow[t]{2}{*}{$\begin{array}{l}\text { Q 3: Do you think } \\
\text { learning and } \\
\text { speaking English as } \\
\text { a foreign language } \\
\text { is very difficult? } \\
\text { What kind of } \\
\text { difficulties or } \\
\text { problems do you } \\
\text { feel when speaking } \\
\text { English? }\end{array}$} & $\begin{array}{l}\text { Difficult because the writing } \\
\text { and the way we speak is } \\
\text { different, hard because of the } \\
16 \text { tenses, all English is hard } \\
\text { because I don't have basic, } \\
\text { my vocabulary is poor, I don't } \\
\text { understand structure or } \\
\text { grammar }\end{array}$ & $\begin{array}{l}\text { Sometimes easy because I } \\
\text { know the answer, not really hard } \\
\text { because I have joined English } \\
\text { course, my friend helps me so } \\
\text { not difficult }\end{array}$ \\
\hline & Number of interviewees: 19 & Number of interviewees: 11 \\
\hline
\end{tabular}




\begin{tabular}{|c|c|c|}
\hline \multirow[t]{2}{*}{$\begin{array}{l}\text { Q 4: What kinds of } \\
\text { situations cause } \\
\text { stress or anxiety for } \\
\text { you? }\end{array}$} & $\begin{array}{l}\text { English written test because I } \\
\text { don't know much, speaking } \\
\text { test because I am nervous } \\
\text { and I can't remember what to } \\
\text { say, speaking in front of } \\
\text { people because I am not } \\
\text { confident, all English test } \\
\text { made me stressful because I } \\
\text { have zero English, English } \\
\text { presentation because hard; } \\
\text { the preparation and the } \\
\text { delivery }\end{array}$ & Number of interviewees: 2 \\
\hline & Number of interviewees: 28 & \\
\hline $\begin{array}{l}\text { Q 5: What happens } \\
\text { to you when you are } \\
\text { in a stressful } \\
\text { situation while } \\
\text { speaking English } \\
\text { and what do you do } \\
\text { in these } \\
\text { kinds of situations? }\end{array}$ & $\begin{array}{l}\text { Tremble, overuse gestures, } \\
\text { blank, Want to cry, speak } \\
\text { short because what I } \\
\text { memorize is almost gone } \\
\text { away, I finish my speaking } \\
\text { and sit, I speak with low } \\
\text { voice, I don't want to speak } \\
\text { Number of interviewees: } 20\end{array}$ & $\begin{array}{l}\text { Take a deep breath and } \\
\text { continue to speak, I repeat what } \\
\text { I want to say and deep down in } \\
\text { my heart I say I can do it, I beat } \\
\text { my nervousness I say to myself } \\
\text { if somebody can do this, so do I. } \\
\text { Number of interviewees: } 10\end{array}$ \\
\hline $\begin{array}{l}\text { Q 6: What do you } \\
\text { think are the } \\
\text { reasons of this } \\
\text { nervousness or } \\
\text { anxiety? }\end{array}$ & $\begin{array}{l}\text { Lack of knowledge because } \\
\text { my lecturer's explanation is } \\
\text { unclear, not get used to } \\
\text { speak in front of many } \\
\text { people, I think English so } \\
\text { difficult to learn, I am not } \\
\text { interested in English. I don't } \\
\text { know what to say so I am } \\
\text { nervous. I am afraid of } \\
\text { making mistake, don't get } \\
\text { much experience to speak } \\
\text { English in front of the public. } \\
\text { Number of interviewees: } 30\end{array}$ & \\
\hline $\begin{array}{l}\text { Q 7: In which kind of } \\
\text { situations do you not } \\
\text { feel anxiety or feel } \\
\text { motivated while } \\
\text { speaking English? }\end{array}$ & $\begin{array}{l}\text { When we aren't required to } \\
\text { give presentation, speak in } \\
\text { front of the class, not being } \\
\text { pointed during the class to } \\
\text { speak. When only my lecturer } \\
\text { speaks } \\
\text { Number of interviewees: } 22\end{array}$ & $\begin{array}{l}\text { When I understand my lecturer's } \\
\text { explanation with clear } \\
\text { instruction. When my friends } \\
\text { support me to speak (nobody } \\
\text { laughs), when the lecturer } \\
\text { doesn't give long explanation } \\
\text { make us confused, when the } \\
\text { class is fun no pressure }\end{array}$ \\
\hline & & Number of interviewees: 8 \\
\hline $\begin{array}{l}\text { Q 8: Are you afraid } \\
\text { of making errors } \\
\text { while speaking } \\
\text { English and how do } \\
\text { you think people will } \\
\text { react if you make }\end{array}$ & $\begin{array}{l}\text { Yes and my friends will } \\
\text { laugh. Of course, my } \\
\text { classmates will laugh at me } \\
\text { and it makes my mental } \\
\text { down. Sure, I feel ashamed. } \\
\text { Yes, I feel so stupid when }\end{array}$ & $\begin{array}{l}\text { Not really because I don't care. I } \\
\text { am okay with making mistake } \\
\text { because I think nobody is } \\
\text { prefect. I don't bother because } \\
\text { my classmates will support me. I } \\
\text { feel okay because that's what }\end{array}$ \\
\hline
\end{tabular}


Sitti Nur Aisyah Ritonga. 3(1): 198-213

\begin{tabular}{|c|c|c|}
\hline mistakes? & $\begin{array}{l}\text { making mistake because my } \\
\text { lecturer will be angry. } \\
\text { Number of interviewees: } 17\end{array}$ & $\begin{array}{l}\text { learning for } \\
\text { Number of interviewees: } 13\end{array}$ \\
\hline $\begin{array}{l}\text { Q 9: How do you } \\
\text { think your language } \\
\text { teacher plays a role } \\
\text { in creating or } \\
\text { reducing the feeling } \\
\text { of anxiety? }\end{array}$ & $\begin{array}{l}\text { My lecturer is serious when } \\
\text { explaining. } \\
\text { My lecturer is not friendly } \\
\text { enough. } \\
\text { Number of interviewees: } 13\end{array}$ & $\begin{array}{l}\text { My lecturer claps showing some } \\
\text { support when we don't know } \\
\text { how to speak } \\
\text { My lecturer guides us to speak. } \\
\text { Number of interviewees: } 17\end{array}$ \\
\hline $\begin{array}{l}\text { Q 10: What would } \\
\text { you like to suggest } \\
\text { in order to reduce } \\
\text { language anxiety in } \\
\text { the learners and } \\
\text { show a strong } \\
\text { motivation? }\end{array}$ & $\begin{array}{l}\text { Change the lecturer } \\
\text { Don't give us much task to do } \\
\text { No more English peaking } \\
\text { class } \\
\text { Number of interviewees: } 5\end{array}$ & $\begin{array}{l}\text { Fun learning English with many } \\
\text { games } \\
\text { No more long explanation } \\
\text { Interactive class } \\
\text { Teaching from basic because } \\
\text { most of us have lack of English } \\
\text { knowledge } \\
\text { The method of teaching } \\
\text { Supportive classmates and } \\
\text { lecturer } \\
\text { Lecturer who understands } \\
\text { enough the psychological } \\
\text { factors of the students }\end{array}$ \\
\hline & & Number of interviewees: 25 \\
\hline $\begin{array}{l}\text { Q11: How often do } \\
\text { you practice } \\
\text { speaking outside the } \\
\text { classroom? }\end{array}$ & $\begin{array}{l}\text { Never because I don't care. } \\
\text { Never, because I don't know. }\end{array}$ & $\begin{array}{l}\text { Usually because I have joined a } \\
\text { course and I practice there } \\
\text { Sometimes, I study by myself at } \\
\text { home } \\
\text { Sometimes, I watch English film. } \\
\text { Rarely, I practice with my } \\
\text { friends. } \\
\text { Sometimes, I join English club } \\
\text { or competition. } \\
\text { Sometimes, when there is a } \\
\text { speaking test. }\end{array}$ \\
\hline & & Number of interviewees: 23 \\
\hline $\begin{array}{l}\text { Q12: What do you } \\
\text { think about the } \\
\text { importance of } \\
\text { English speaking } \\
\text { skills to your future } \\
\text { career? }\end{array}$ & $\begin{array}{l}\text { Unimportant; I don't want to } \\
\text { be English teacher later } \\
\text { Very unimportant ; because } \\
\text { we can also have job without } \\
\text { English }\end{array}$ & $\begin{array}{l}\text { Normal; because we don't need } \\
\text { to speak English all the time } \\
\text { when having a job as an English } \\
\text { teacher } \\
\text { Important; because I will be } \\
\text { English teacher } \\
\text { Very important; because many } \\
\text { people have job with English } \\
\text { knowledge and every } \\
\text { technology use having English } \\
\text { instruction }\end{array}$ \\
\hline
\end{tabular}

Number of interviewees: 24 


\begin{tabular}{|c|c|c|}
\hline $\begin{array}{l}\text { Q13: How do you } \\
\text { feel in speaking } \\
\text { class? }\end{array}$ & $\begin{array}{l}\text { Much pressure } \\
\text { Anxious } \\
\text { Unconfident } \\
\text { Confused } \\
\text { Lazy } \\
\text { Unclear }\end{array}$ & $\begin{array}{l}\text { Motivated } \\
\text { Interested } \\
\text { High spirit } \\
\text { So so } \\
\text { Sometimes lazy, sometimes } \\
\text { diligent }\end{array}$ \\
\hline & Number of interview: 14 & Number of interviewees: 16 \\
\hline $\begin{array}{l}\text { Q14: What would be } \\
\text { the result of study } \\
\text { for students with } \\
\text { language } \\
\text { motivation? }\end{array}$ & & $\begin{array}{l}\text { Speak fluent in English } \\
\text { Speak well } \\
\text { Confident to speak } \\
\text { Show better speaking skill } \\
\text { Good score } \\
\text { Good achievement }\end{array}$ \\
\hline $\begin{array}{l}\text { Q15: What would be } \\
\text { the result of study } \\
\text { for students with } \\
\text { language anxiety? }\end{array}$ & $\begin{array}{l}\text { Shy to speak in front of } \\
\text { people } \\
\text { Average students } \\
\text { Students with low } \\
\text { achievement } \\
\text { No achievement }\end{array}$ & \\
\hline
\end{tabular}

The interview below was the result conducted for the English speaking lecturer.

Table 2. The presentation of question and responses in interview

\begin{tabular}{ll}
\hline \multicolumn{1}{c}{ Questions } & \multicolumn{1}{c}{ Response } \\
\hline Q1: How do you view the role of "In my opinion, anxiety could be the \\
language anxiety for learners in stimulus for students to deal with their \\
learning and particularly speaking \\
English language? \\
$\begin{array}{l}\text { speaking class either positive act or } \\
\text { negative act. It depends on the way } \\
\text { students respond to this feeling." }\end{array}$ \\
\hline language classroom activities have \\
you found to be anxiety- provoking for \\
the students?
\end{tabular}


Q 6: How do you think language anxiety can be successfully controlled in the learners?

Q 7: What efforts you have been done in order to overcome anxiety?
"As I told before, language anxiety can be positive or negative. If the students let themselves feel down, negative results will control them, vice versa"

"Support them while get stuck or don't know what to say in front of the public. Guide them step by step so they will be able to speak without thinking too much. Motivate them through some figures who finally get scholarship and continue their studies overseas due to their English skills."

Q 8: Do you agree that mastering English is really great?

"Totally agree. English nowadays has become a way for people to achieve their higher education."

Q9: Do you have any ideas of how English classes might be motivating?

"Create a friendly environment for the learners; not provoking and no pressure."

Q10: Which students would probably perform better on speaking? Those with language anxiety or language motivation?
Language anxiety would create low achievement even no achievement for students. So, I believe motivated students perform better in speaking skill.

\subsection{The Result of the Questionairre}

There were two kinds of questionairre diistributing to the students. First is a FLCAS (Foreign Language Classroom Anxiety Scale) questionnaire proposed by Horwitz et al. (1986) and questionnaire of motivation in learning EnglishAttitude/Motivation Test Battery (AMTB) by Gardner, 1985 that was plan to meet the needs of this research to find out the sources of their anxiety and motivation in English speaking classroom.

Table 3. Number of The Students Who Opted For Each Choice Of Each Item In

The Flcas $\mathrm{Sa}=$ Strongly Agree, $\mathrm{A}=$ Agree, $\mathrm{N}=$ Neither Agree Nor Disagree,

$\mathrm{D}=$ Disagree, And $\mathrm{Sd}=$ Strongly Disagree

\begin{tabular}{|l|l|l|l|l|l|l|}
\hline No & Item & SA & A & N & D & SD \\
\hline 1 & $\begin{array}{l}\text { I never feel quite sure of myself when I am } \\
\text { speaking in English. }\end{array}$ & 8 & 20 & 35 & 26 & 32 \\
\hline 2 & $\begin{array}{l}\text { I don't worry about making mistakes in English } \\
\text { class. }\end{array}$ & 17 & 23 & 20 & 56 & 5 \\
\hline 3 & $\begin{array}{l}\text { I tremble when I know that I'm going to be called } \\
\text { on in English class. }\end{array}$ & 9 & 27 & 33 & 46 & 6 \\
\hline 4 & $\begin{array}{l}\text { It frightens me when I don't understand what the } \\
\text { teacher is saying in English. }\end{array}$ & 4 & 32 & 20 & 53 & 12 \\
\hline 5 & $\begin{array}{l}\text { It wouldn't bother me at all to take more English } \\
\text { classes. }\end{array}$ & 7 & 13 & 9 & 43 & 49 \\
\hline 6 & $\begin{array}{l}\text { During English class, I find myself thinking about } \\
\text { things that have nothing to do with the course. }\end{array}$ & 2 & 22 & 32 & 46 & 19 \\
\hline 7 & $\begin{array}{l}\text { I keep thinking that the other students are better } \\
\text { at English than I am. }\end{array}$ & 1 & 12 & 32 & 55 & 21 \\
\hline 8 & $\begin{array}{l}\text { I am usually at ease during tests in my English } \\
\text { class. }\end{array}$ & 12 & 13 & 45 & 43 & 8 \\
\hline 9 & $\begin{array}{l}\text { I start to panic when I have to speak without } \\
\text { preparation in English class. }\end{array}$ & 10 & 64 & 13 & 23 & 11 \\
\hline
\end{tabular}




\begin{tabular}{|c|c|c|c|c|c|c|}
\hline 10 & $\begin{array}{l}\text { I worry about the consequences of failing my } \\
\text { English class. }\end{array}$ & 33 & 37 & 12 & 34 & 5 \\
\hline 11 & $\begin{array}{l}\text { I don't understand why some people get so upset } \\
\text { over English classes. }\end{array}$ & 23 & 42 & 48 & 34 & 13 \\
\hline 12 & $\begin{array}{l}\text { In English class, I can get so nervous I forget things } \\
\text { I know. }\end{array}$ & 17 & 35 & 38 & 21 & 11 \\
\hline 13 & $\begin{array}{l}\text { It embarrasses me to volunteer answers in my } \\
\text { English class. }\end{array}$ & 11 & 21 & 25 & 33 & 31 \\
\hline 14 & $\begin{array}{l}\text { I would not be nervous speaking English with native } \\
\text { speakers. }\end{array}$ & 7 & 32 & 30 & 23 & 29 \\
\hline 15 & $\begin{array}{l}\text { I get upset when I don't understand what the } \\
\text { teacher is correcting. }\end{array}$ & 3 & 29 & 15 & 51 & 23 \\
\hline 16 & $\begin{array}{l}\text { Even if I am well prepared for English class, I } \\
\text { feel anxious about it. }\end{array}$ & 7 & 21 & 23 & 31 & 39 \\
\hline 17 & I often feel like not going to my English class. & 9 & 59 & 25 & 13 & 15 \\
\hline 18 & I feel confident when Is & & & & & 9 \\
\hline 19 & $\begin{array}{l}\text { I am afraid that my } \\
\text { correct every mistal }\end{array}$ & 4 & 25 & 27 & 42 & 23 \\
\hline 20 & $\begin{array}{l}\text { I can feel my heart pounding when I'm going to be } \\
\text { called on in English class. }\end{array}$ & 35 & 43 & 21 & 13 & 9 \\
\hline 21 & $\begin{array}{l}\text { The more I study for an English test, the more } \\
\text { confused I get. }\end{array}$ & 3 & 8 & 7 & 53 & 50 \\
\hline 22 & $\begin{array}{l}\text { I don't feel pressure to prepare very well for } \\
\text { English class. }\end{array}$ & 3 & 5 & 10 & 53 & 50 \\
\hline 23 & $\begin{array}{l}\text { I always feel that the other students speak the } \\
\text { foreign language better than I do. }\end{array}$ & 4 & 13 & 45 & 37 & 21 \\
\hline 24 & $\begin{array}{l}\text { I feel very self-conscious about speaking the } \\
\text { English language in front of other students. }\end{array}$ & 2 & 15 & 32 & 42 & 30 \\
\hline 25 & $\begin{array}{l}\text { English class moves so quickly. I worry about } \\
\text { getting left behind. }\end{array}$ & 4 & 11 & 19 & 63 & 24 \\
\hline 26 & $\begin{array}{l}\text { more tense and nervous in my English } \\
\text { than in my other classes. }\end{array}$ & 3 & 15 & 19 & 47 & 39 \\
\hline 27 & $\begin{array}{l}\text { I get nervous and confused when I am speaking } \\
\text { my English class. }\end{array}$ & 2 & 9 & 31 & 78 & 40 \\
\hline 28 & $\begin{array}{l}\text { When I'm on my way to English class, I feel very } \\
\text { sure and relaxed. }\end{array}$ & 13 & 15 & 47 & 44 & 2 \\
\hline 29 & $\begin{array}{l}\text { I get nervous when I don't understand every word } \\
\text { the English teacher says. }\end{array}$ & 65 & 30 & 35 & 3 & 25 \\
\hline 30 & $\begin{array}{l}\text { I feel overwhelmed by the number of rules you } \\
\text { have to learn to speak English. }\end{array}$ & 4 & 25 & 23 & 49 & 20 \\
\hline 31 & $\begin{array}{l}\text { I am afraid that the other students will laugh at } \\
\text { me when I speak English. }\end{array}$ & 47 & 25 & 24 & 7 & 20 \\
\hline 32 & $\begin{array}{l}\text { I would probably feel comfortable around native } \\
\text { speakers of English. }\end{array}$ & 15 & 51 & 31 & 23 & 1 \\
\hline 33 & $\begin{array}{l}\text { I get nervous when the English teacher asks } \\
\text { questions which I haven't prepared in advance. }\end{array}$ & 13 & 47 & 27 & 22 & 13 \\
\hline
\end{tabular}

In answering this question, you should have circled one alternative. Some people would have circled "Strongly Disagree", others would have circled "Strongly Agree", while others would have circled any of the alternatives in between. Which one you choose would indicate your own feeling based on everything you know and have heard. Note: there is no right or wrong answer. 
Table 4. Number of The Students Who Opted For Each Choice Of Each Item In The Flcas $\mathrm{Sa}=$ Strongly Agree, $\mathrm{A}=$ Agree, $\mathrm{N}=$ Neither Agree Nor Disagree,

$\mathrm{D}=$ Disagree, And $\mathrm{Sd}=$ Strongly Disagree

\begin{tabular}{|l|l|l|l|l|l|l|l|}
\hline No & \multicolumn{1}{|c|}{ Item } & \multicolumn{1}{|c|}{$\mathbf{1}$} & $\mathbf{2}$ & $\mathbf{3}$ & $\mathbf{4}$ & $\mathbf{5}$ & $\mathbf{6}$ \\
\hline 1 & $\begin{array}{l}\text { I have high motivation to learn English in order } \\
\text { to communicate with English speaking people. }\end{array}$ & 3 & 13 & 24 & 35 & 27 & 19 \\
\hline 2 & $\begin{array}{l}\text { I have a positive attitude toward English } \\
\text { speaking people. }\end{array}$ & 11 & 10 & 15 & 13 & 34 & 38 \\
\hline 3 & $\begin{array}{l}\text { I have a very high interest in English } \\
\text { language. }\end{array}$ & 21 & 3 & 13 & 17 & 45 & 22 \\
\hline 4 & I have a strong desire to learn English. & 6 & 23 & 16 & 30 & 32 & 14 \\
\hline 5 & $\begin{array}{l}\text { I like my English class so much, I look forward } \\
\text { to studying more English in the future. }\end{array}$ & 9 & 11 & 27 & 11 & 29 & 34 \\
\hline 6 & $\begin{array}{l}\text { My English teacher is a great source of } \\
\text { inspiration to me. }\end{array}$ & 19 & 4 & 13 & 31 & 33 & 21 \\
\hline 7 & $\begin{array}{l}\text { Studying English is important because it will } \\
\text { be useful in getting a good job. }\end{array}$ & 19 & 12 & 7 & 18 & 23 & 41 \\
\hline 8 & $\begin{array}{l}\text { I worry about speaking English outside of } \\
\text { class. }\end{array}$ & 27 & 36 & 23 & 14 & 11 & 10 \\
\hline 9 & English class is my favorite. & 31 & 2 & 6 & 15 & 17 & 50 \\
\hline 10 & I worry about speaking in my English class & 32 & 21 & 21 & 14 & 16 & 17 \\
\hline 11 & I wish I were fluent in English. & 31 & 16 & 2 & 19 & 41 & 12 \\
\hline 12 & $\begin{array}{l}\text { My parents encourage me to practice my } \\
\text { English as much as possible. }\end{array}$ & 15 & 10 & 13 & 23 & 29 & 31 \\
\hline
\end{tabular}

Legend: 1. Strongly Disagree, 2. Moderately Disagree, 3. Slightly Disagree, 4. Slightly Agree, 5. Moderately Agree, and 6. Strongly Agree

\section{Discussion}

\subsection{Effect of Motivation and Anxiety on Students' Speaking Performance}

\section{a. Observation}

From the observation, it can be concluded that motivated learners could engage actively in the classroom activity. Their active participations lead them to boost their proficiency in speaking English. As Ur (1996) said that the more motivated the learners the higher their learning process is. So, the more motivated the learner the higher their speaking ability is. With good motivation, the students are going to put much effort to anything that may improve their speaking achievement. They are going to try and finish speaking task. They also will try and practice their speaking with their friends without being afraid to create mistakes. The more practice in speaking, the higher their English skill is. The students who had good enough motivation dare to perform their speech in front of the public. Making errors stimulate them to do better in the next opportunity.

Meanwhile, students with anxiety will not perform better in speaking class. They tend to be afraid of making errors and fear of speaking in front of the class. The studies between language anxiety and language skills have mostly related to the oral performance (Horwitz, et. al., 1986; Aida, 1994). Most anxiety studies in a language learning situation appear to be associated with the oral aspect (Horwitz et.al, 1986; Young, 1991; Daly, 1991; Philips, 1992). This 
means that, as mentioned earlier, of the fours skills, speaking is probably considered the most stressful for second language learners.

\section{b. Interview}

From the interview, the researcher could classify learners with motivation and anxiety based on the way they answered the questions. Most of the participants responded that classroom atmosphere plays a pivotal role in which they feel motivated with the lesson taught. By having a motivated feeling, an effective and effiecent learning could be gained which later triggers the learners to perform better in speaking skill (English speaking mastery). $43.3 \%$ students responsed to question number 1 indicated student with language motivation while $57 \%$ categorized as students with language anxiety. In addition, they were also asked about their feelings attending English speaking class. $53.3 \%$ of students responded that they feel motivated and interested while the rest answered there was a pressure and laziness to attend the class.

On the other hand, when students being asked what would be the result of study for those who are motivated and experience anxiety. They all agreed that motivated students would probably have linguistic competence to produce language performance. Whereas, students with dominantly having language anxiety would experience nervousness and high tension when speaking which are trapped them to go extra mile in mastering English speaking.

In further, researcher interviewed the lecturer to obtain data from both sides objectively. In general, the lecturer seemed fully realizing about the language anxiety and mitivation in L2 class. He could explain in detail every aspect the researcher ask. He assumed that overuse gestures when speaking, sweating, tension, and have no idea what to speak, afraid of making errors were the indication of language anxiety while motivation was shown from being confident, intiative to do the task, engage actively and positively during the learning processs.

The lecturer believed that students with no intention to show their best in speaking English (no achievement) were the effect of anxiety the experienced. Besides that, the effect of motivation could be clearly seen for the learners who tried, practiced, and performed their best during the speaking session.

\section{c. Questionnaire}

On the first questionairre (FLCAS), $61 \%$ learners stared to panic when they have to speak without preparation in English class. It shows that their anxiety is highly controlled them. Students were getting so nervous when they don't understand every word the English teacher says are calculated $78 \%$. It was also seen during the observation, so nervousness is the major impact of the students' anxiety. 56\% learners felt like not going to their English class meaning that they showed their disinterest to their English speaking class. In the next, heart pounding when going to be called on in English class was felt by the students in $64 \%$. Being afraid that the other students will laugh at me when speaking English was at $59 \%$. On the item for not feeling pressure to prepare very well for English class, only $6 \%$ of learners agreed. Thus, the 
effect of anxiety on Students' Speaking Performance was clearly shown by inability of the students to engage well in speaking class.

On the other questionairre which is AMTB,34 \% students had high motivation to learn English in order to communicate with English speaking people. Have a very high interest in English language was responded by $55 \%$ learners. Only $49 \%$ of learners disagreed that they don't like my English class so much, they look forward to studying more English in the future. $52 \%$ learner go with the statement that studying English is important because it will be useful in getting a good job. So students wished they were fluent in English are claculated $43 \%$. At the item of parents encourage me to practise my English as much as possible were only reponded by $49 \%$ students. Consequently, their motivations in the class to study were clearly seen from their responsive participation and their ability to go further achieveing better speaking proficiency.

\section{d. How Students' Control Their Anxiety}

Based on the interview result to both students and teacher, students assumed that the way they control their anxiety is by taking a deep breath and continue to speak, repeating what to say and stimulatng their internal motivation by saying "I can do it", beating their nervousness by motivating themselves and taking good example from motivated figures. Meanwhile the teacher said that, if the students focused on negative things that made their mental down, language anxiety controls them a lot. So, to hold back ourself is by thinking positively eventhough bad things happened. You yourself keep your enthusiasm on fire.

\section{e. Suggestions to Create Friendly Classroom Environment oriented to Speaking Skill Mastery}

In 1960s, there was a method called Communicative Language Teaching. The communicative approach is based on the idea that learning language successfully comes through having to communicate real meaning. When learners are involved in real communication, their natural strategies for language acquisition will be used, and this will allow them to learn to use the language (tesol.com). Language learning is learning to communicate using the target language. The language used to communicate must be appropriate to the situation, the roles of the speakers, the setting and the register. The learner needs to differentiate between a formal and an informal style (British Council). Based on the explanation above, the researcher assured that teaching English should be easy, practical, and communicative.

\section{Conclusion}

The first hypothesis assumed that language anxiety felt by students during their speaking presentation in English might result in their inability to deliver ideas clearly and this would have a negative impact on their performance. This was reflected by their confused and jumbled thoughts and being stuck not know what to do or to interact with the audience, in addition to their physical signs of anxiety. In contrast, langauge motivation during speaking presentation would help students to feel less anxious and be more concentrated on the task 
and would result in a better speaking performance. The impact of motivation on learners was positive. This was revealed by structured organization in their deliveries, their interest and ability to perform well. The speaking presentation gained the appreciation of both the audience and the teacher. Both aspects stated above as the first hypothesis were confirmed as the main findings of this study. All in all, langauge anxiety has a negative effect on learners while motivation is needed, for this reason a student has to make a balance between both variables in order to achieve the best performance. Researcher also suggested that it is most likely effective to deliver the teaching of English speaking with 3 principles. They are easy, practical, and communicative. By knowing our students' need, teacher/ lecturer could design the best material to be delivered which in further could achieve the effictive and efficient learning process. Students would obviously enjoy the class very much. At the end, nice classroom atmospehere with better performance of students in speaking is achieved well.

\section{References}

Al Kaboody, Mastoor. (2013). Second Language Motivation; The Role of Teachers in

Aswad, M et.al. 2019. A Software to increase English Learning Outcomes: An Acceleration Model of English as the Second Language. The Asian EFL Journal 26 (6.2.2019), 157-169

Brown, H. (2007). Principles of Language Learning and Teaching. Fifth edition.Addison Wesley

Elaine K. Horwitz, Michael B. Horwitz, Joann Cop. 2012. Foreign Language Classroom Anxiety. (Online) Vol. 70 No. 2, (https://www.researchgate.net/publication/256495249_English_Language Learning_Anxiety_among_Foreign_Language_Learners_in_the_Philippine s, accessed on 28th January 2020).

Hosseini. 2013. Language Learners' Attitudes And Beliefs: Brief Review of The Related Literature And Frameworks [Ellis' Theory cited]. (Online serial) avilable from: URL: HYPERLINK http://ijonte.org/FileUpload/ks63207/File/06a.hosseini.pdf

International Conference on Education and Educational Psychology (ICEEPSY 2011) (Brown's Theory Cited), IRAN Payame Noor University: University: 2011. Available from: https://www.researchgate.net/publication/271638356_Motivation_attitude_ and_language_learning

Krashen, Stephen D. (1998). Second Language Acquisition and Second Language Learning. (Online serial) downloaded in 3rd January 2020. Available from : URL: HYPERLINK http://www.sdkrashen.com/content/books/sl_acquisition_and_learning.pdf

Learners' Motivation (Dörnyei's Theory Cited). Vol. 3(4) February. Available from: 
https://www.academia.edu/11130725/Second_Language_Motivation_The _Role_of Teachers_in_Learners_Motivation

Rahman, Fathu (2018). The Constraints of Foreign Learners in Reading English Literary Works: A Case Study at Hasanuddin University. Journal of Arts \& Humanities (JAH) 7 (02, 2018), 01-12

Research Gate Net. 2017. Emotion-focused therapy of depression (Greenberg's Theory Cited). (Serial Online). Available from:

https://www.researchgate.net/publication/317349636_Emotionfocused_therapy_of_depression

Saunders. (2018). Saturation in Qualitative Research. (Serial Online). Available from: https://www.ncbi.nlm.nih.gov/pmc/articles/PMC5993836/

The University of Western Ontario, Canada. (2004). Attitude/Motivation Test Battery: International AMTB Research Project (English version). (Online Serial). Avalable from:

https://publish.uwo.ca/ gardner/docs/englishamtb.pdf

Wolman and Stricker. (1994). Anxiety and Related Disorders: A Handbook.

(Online Serial) downloaded at 16th December 2019. Available from: URL: HYPERLINK https://www.freepsychotherapybooks.org/ebook/anxiety-andrelated-disorders-a-handbook/ 